\title{
ASEAN SOCIETY, A DYNAMIC EXPERIMENT FOR SOUTH-EAST ASIAN REGIONAL CO-OPERATION ${ }^{\star}$
}

\author{
Sompong Sucharitkul *
}

\section{THE PRE-DAWN OF A NEW PACIFIC ERA}

For centuries preceding the advent of modern international law, transfrontier trade in the eyes of the European world was concentrated around the European Mediterranean Basin where transboundary transactions abounded. The laws and customs of external trade had developed a system of jus commune $e^{1}$ observed and adhered to in practice by traders and merchants across and adjacent the Mediterranean costs. A kind of maritime usage grew into what was codified as consolato del mare 2 or a code of conduct for maritime commerce and the carrying trade. A rudimentary form of lex mercatoria ${ }^{3}$ or "law merchant" appeared to have been in operation among the Hanseatic city States and the Italian city republics bordering the Mediterranean, Venice, Naples, Florence and Genoa. A network of commercial and diplomatic relations was established in the early fifteenth

\footnotetext{
* San Francisco, August 1991. This is an introductory study of the chronological steps leading to the formation of the Association of South-East Asian Nations (ASEAN), encapsulating certain important activities undertaken by the regional organisation in the early years of its existence, and indicating progressive trends of its growth and developments up to 1990.

** B.A.Hons, B.C.L., M.A., D.Phil., D.C.L. (Oxford); Docteur en droit (Paris); LL.M. (Harvard); of the Middle Temple, Barrister-at-Law (United Kingdom); Distinguished Visiting Professor of International and Comparative Law (Golden Gate University School of Law); Member of the Institut de droit international; Corresponding Collaborator of UNIDROIT; Member of ICSID Panels of Conciliators and of Arbitrators (World Bank).

1. "Jus commune" or law common to transboundary trade was developed from the 8 th century onwards to regulate international trade.

2. "Consolato del mare" was a private collection of rules and customs of maritime law published in the 14th century in Barcelona. An earlier collection of the Rhodian maritime laws were compiled between the 7 th and 9 th century.

3. For "lex mercatoria", see, e.g., "La lex mercatoria dans les contrats et l'arbitrage internationaux: réalité et perspectives”, JDI (1979) p.106.
}

Ko Swan Sik et al. (eds.), Asian Yearbook of International Law, 113-148.

(c) 1993 Kluwer Arademir Puhlishers. Printed in the Netherlands. 
century over 150 trading cities and centres in Europe. Since the Treaty of Westphalia (1648), the trade centre of the world has moved from the Mediterranean to the Atlantic. Today, in the closing decade of the twentieth century, the world's trade centre is moving away from the Atlantic to the Pacific. At the turn of the nineteenth century, a US Secretary of State ${ }^{4}$ said: "The Mediterranean is the ocean of the past, the Atlantic the ocean of the present, the Pacific the ocean of the future". These predictions have been confirmed by the current unprecedented growth and rise of the Pacific Rim. Today, the Mediterranean is the sea of historic significance. The Atlantic is the ocean of current commercial competition, of conflict of political interests and rivalry, of disintegrating military alliances and of traumatic transformation to achieve unification and harmonisation. The Pacific Rim is the rising unspoiled terra nova on which to receive and sustain the massive economic shift progressively taking place from the aging Atlantic Rim, especially the East and North-East Atlantic cities. This ongoing shift from the Atlantic to the Pacific is propelled by the dynamic force of sheer economics. It is also accompanied by a cultural shift as the Pacific Rim countries have proved more versatile, speaking more than a thousand languages and practising the most varied religious and cultural traditions in the world. This is being further reinforced by increasing emphasis on education and scientific research as a key to the improvement of manpower. It has been suggested that the Pacific Rim cities on the continent of North America like San Francisco and Portland, Oregon, should capitalize on the current shift into the century of the Pacific. ${ }^{5}$ This is one of the challenges to be addressed before the close of the twentieth century.

The gentle persuasiveness of the Pacific Rim in regard to tourism, trade and investment is enhanced by the comforting assurance that the shift from the Atlantic to the Pacific does not necessarily entail any decline on the part of the West relative to the East. But even such a dichotomy of "East and West" is history today as it is devoid of tangible foundation. The contrast is unreal. Thus, San Francisco is on the West coast of the United States but it is equally a city on the Eastern seaboard of the Pacific Rim. What is West from the standpoint of Mexico, Canada or the United States is clearly East, North-East or Near East in the objective perspective of the Pacific Rim.

Apart from the sporadic existence of highly developed economies dotting the Pacific Rim in all directions, the United States, Canada, the USSR, Japan, Australia and New Zealand, there have now emerged from the Pa-

4. The Honorable Jor iN HAY was US Secretary of State who made the prophecy. The expression "ocean" when applied to the Mediterranean was used metaphorically.

5. See, e.g., John Naisbitt and Patricia Aburdene, Mega Trends 2000 (Pan Books (1990)) at $\mathrm{pp}, 158-193$. 
cific ocean no fewer than four giants or tigers or dragons, if such an expression is to be preferred, viz., Singapore, Taiwan (ROC), Hong Kong and Korea (ROK). These tigers have been nicknamed NIC, the Newly Industrialised Countries. ${ }^{6}$ The next in line to become another NIC may include Thailand, Malaysia, the Philippines and Indonesia, all being founding members of ASEAN. It should be added that the sixth ASEAN member, Brunei Darussalam, has the highest GNP per capita ${ }^{7}$ in the whole world exceeding that of Kuwait. What appears startling is the continuing growth at an unprecedented pace of the magnitude of tourism, trade and investment among the countries of the Pacific Rim. A new partnership in these fields has apparently emerged among the fast-growing economies of the Asian Pacific. According to the latest forecast of the Pacific Economic Co-operation Conference prepared by the United States National Committee for Pacific Economic Cooperation, ${ }^{8}$ the slow growth of 5.0 percent has ended in 1990 and economic growth rate will rise again in 1991. The fastest growing economies in the Pacific are now to be found in ASEAN, whose growth leader happens to be Thailand, followed closely by Singapore and Malaysia. All ASEAN countries, with the exception of Brunei, expect faster growth than the average for the region as a whole, although somewhat less than their own 1988-89 performance. The fastest growing countries may still be expanding more than their long-term potential. Taiwan and Korea are also expected to grow faster than the average although less than their recent spectacular performance. From 1992 Taiwan will slow down on her overseas investment but will reinvest in her own national infrastructure to the tone of US $\$ 330$ billion during the ensuing three years.

Pacific growth in tourism, trade and investment is clearly discernible in United States trade patterns. Today, the United States exports more to Korea (ROK) than to France and more to Taiwan than to Italy and Sweden combined. From 1983 onwards, the US-Pacific trade has surpassed its Atlantic trade. While in 1960 United States trade with Asia was only half its trade with Western Europe, in 1983 United States trade with Asia was 50 per cent higher than with Europe, reaching well over US $\$ 300$ billion in 1988, not counting reciprocal investments in tourism. Today, United States trade with Asian Pacific has nearly doubled its trade with European Atlantic.

6. It should be observed that in the European context the same acronym NIC means Newly Integrated Countries, i.e., integrated into the European Community. These include the three latest members of the EEC: Greece, Spain and Partugal. Not unlike the Pacific Rim Tigers, the extension is likely to grow in Europe.

7. GNP par capita of Brunei is more than US $\$ 26,000$. This is twice that of Japan, but may be slightly lower than that of Nauru, a Pacific Island nation or the Falkland Islands.

8. Pacific Economic Outlook 1990-91 (Pacific Economic Co-operation Conference. The Pacific Rim Forum, San Francisco, 9-12 September 1990). 
Pacific Rim partnership in trade, investment and tourism appears to be achieving the fastest growing rate of expansion. Being astride the Atlantic and the Pacific, American and Canadian traders and investors are expected to be pragmatic and flexible enough to capitalize on the ideal ambivalent position of the United States and Canada. For these reasons, global attention is now being turned to the phenomenal increase and expansion of trade, investment and tourism among the partners around the Pacific Basin. It is not the purpose of this study to identify the major causes of such growth which are to be found in the economic driving forces, in the practical commercial dexterity of the Asian Pacific traders, in their resourcefulness and resilience. Let us endeavour to observe at closer range the concept of ASEAN partnership at work and then examine the evertightening co-operation between ASEAN and its trading partners on the $\mathrm{Pa}$ cific Rim and yonder.

\section{ASEAN COOPERATION: AN ALTERNATIVE TO SECREGATED CO-EXISTENCE}

Having established an impressive record of the fastest economic growth rate among the fast growing economies of the Pacific Rim, we should invite ourselves to visit ASEAN and to watch the Association of South-East Asian Nations at work. The success story of ASEAN deserves to be told by someone closely associated with the Organisation, although this is not to suppose as a matter of course that all commentaries and studies conducted by outsiders are at best necessarily inaccurate and at worst dangerously misleading in the extreme ${ }^{9}$.

\subsection{The Birth of the Association of South-East Asian Nations}

We may all have a vague notion of ASEAN. For instance, it is no secret that ASEAN is an association for economic co-operation among the countries of the South-East Asian region founded on August 8, 1967. It is also common knowledge that ASEAN consists of five founding members: Thailand, Malaysia, Singapore, Indonesia and the Philippines, while the sixth member, Brunei Darussalam has acceded to the ASEAN Declaration in 1984.

9. See, e.g., a study entitled ASEAN and the United Nations System by JUN NISHIKA (UNITAR 1983). 


\subsubsection{Economic Background}

Further facts and statistics are readily available which tend to confirm the economic strength and potentials of the Association. By way of comparative analysis, for instance, ASEAN in 1991 has a population of well over 300 million, comparable to the enlarged European Economic Communities with unified Germany. As a market, in terms of the size measured by numerical strength of consumers, ASEAN and EEC belong to the same classification. Not unlike the EEC whose smallest member in terms of territory and population, Luxembourg, is probably the richest in GNP per capita and the strongest in industrial development, Brunei and Singapore could share each qualification of Luxembourg. Thailand and the Philippines, each with a population close to sixty million, are comparable to the Federal Republic of Germany, France and Italy in size and population, while Indonesia with a population of more than 170 million has no counterpart unless we lump the United Kingdom together with the South European members of the EEC, Italy, Greece, Spain and Portugal. Malaysia is the approximate size of the Netherlands in terms of population and size of England for acreage of farmland.

Other outstanding statistics concern the over-abundance of identical products rather than complementarity of products to boost intra-ASEAN trade. Three or four members of ASEAN produce as much as 70 to 80 per cent of world production of such as tin (Malaysia, Thailand, Indonesia and Singapore) and natural rubber (Malaysia, Indonesia, Thailand and Singapore), while coconut oil and palm oil (mainly Malaysia and Philippines) and tapioca or manioc (mainly Thailand and Indonesia) are common export items from ASEAN countries. Energy resources such as gas and petroleum products are exported from Indonesia, Malaysia and the Philippines and to some extent refined and exported from Singapore. Rice is exported mainly by Thailand and marginally also by the Philippines. Reciprocal trade exists on sea-food products, foodstuff and textile including silk, batik and handicraft. In the industrial sectors of late, automobiles, electronics, television sets, VCRs, computers, etc., have begun to constitute significant export items from Singapore, Thailand and Malaysia.

There is thus not much incentive to induce intra-regional trade among ASEAN countries, and regional co-operation will have to be based on other economic considerations. The objectives of ASEAN had been economic from the start and should continue to remain so in the foreseeable future. Yet, what has bound up the destinies of ASEAN closely together initially may not be as much economic as social, cultural and political or, indeed, security reasons. South-East Asian Nations must learn individually as well as collectively to survive as independent sovereign nations. 


\subsubsection{Political Motivation}

Economic considerations may have provided the initial reasons for ASEAN to pool their resources together, but it is to a greater degree the necessity to survive as free and independent sovereign nations that has brought ASEAN together. There can be no divorce between political stability and economic growth and development. ASEAN leaders were well aware that their combined economic strength could be marshaled to reinforce their collective political will. Before the establishment of ASEAN, member countries had examined their previous experience with the existing regional organisations for co-operation in trade and development. A quick glance at these forerunners might be in order.

\section{(a) The Asian-African Conference}

The first question to be addressed relates to the national policies of the ASEAN nations which shared some common ideals or principles. The Joint Communique of the First Asian Conference in Bandung, Indonesia, in 1955 offered an attractive indication of some unity of approach. At least three of the ASEAN countries were participants at Bandung: Indonesia, Thailand and the Philippines. Malaysia and Singapore were still in the process of being born. The principles of friendly relations, good-neighbourliness and economic co-operation were declared to be the chosen path of the newly emerged Asian-African world, where freedom, independence, the decolonisation process as well as the Rule of Law remained on the top of the list of priorities. Bandung was, for that matter, by no means the meeting place of exclusively newly emerged countries of Asia and Africa. The oldest Asian nations, Thailand, China and Japan, were active participants, although by that time the last two played no part in the United Nations.

(b) The United Nations Regional Commission (ESCAP)

Mutual co-operation would appear to be a normal instinct among the nascent Asian-African world. But instinct alone did not lead to concrete results as both Asia and Africa individually and intercontinentally were quite divided for innumerable reasons of a religious and cultural nature. Efforts to create a regional organisation for Asia have not met with great success due to the extreme vastness of the area, its diversity and the lack of driving forces in support of a regional organisation for economic cooperation. The regional UN Economic Commission for Asia and the Far East (ECAFE, now ESCAP for: Economic and Social Commission for Asia and the Pacific) served as a task force to foster co-operation within the greater Asian Pacific region. Ministerial Conferences were held and the Council of Ministers for Asian Economic Co-operation was set up to map 
out strategies for economic development and co-operation. The regional UN Commission produced useful and concrete results in certain areas such as the establishment of the Asian Development Bank and the Committee for Co-ordination and Investigation of the Lower Mekong Basin (Thailand, Laos, Cambodia and Vietnam). The Council of Ministers also considered a programme of trade co-operation in Asia and the Pacific, a programme for regional monetary co-operation and other supporting trade development and commercial infra-structures.

(c) Asian Pacific Council (ASPAC)

Other regional economic co-operation initiatives had been taken by the regional countries in the Pacific Rim. Thus, the Asian Pacific Council (ASPAC) was created in 1966 following the Summit of Seoul, ROK, consisting of some ten countries, namely, Korea (ROK), Japan, the Philippines, China (ROC), Thailand, Laos, Vietnam (South), Malaysia, Australia and New Zealand. When seemingly out of nowhere the wind of political change swept across the South China Sea with the change of Chinese representation in the United Nations in 1971 and the fall of Saigon in 1975, ASPAC could not endure the frontal onslaught of the insidious political storm. Gracefully, the Asian Pacific Council played down its profile and slowly dismantled the regional centres it had carefully planned for each country. For instance, Thailand had set up ECOCEN, an Economic Cooperation Centre, China (ROC) a Fertilizer Centre, and Korea (ROK) a Social and Cultural Centre. With the exception of the Social and Cultural Centre in Seoul which retains its raison d'être, other offsprings of ASPAC appear to have fallen into desuetude ratione cessante. Nevertheless, while it lasted, each of the centres created under the auspices of ASPAC did inure for the benefit of the host country as well as all other ASPAC members.

\section{(d) Ministerial Conference for the Economic Development of} South-East Asia (MCEDSEA)

Another regional conference worth mentioning is the Ministerial Conference for the Economic Development of South-East Asia which became functional in 1966. It consists of economic assistance and technical cooperation projects between Japan as donor country and nine or ten South-East Asian nations as recipients of Japanese aid. Japan is now flanked by Australia and New Zealand, and occasionally the recipient countries also count Burma among the participants. Notable examples of projects under MCEDSEA include the South-East Asia Fisheries Centre with a Training Section in Thailand and a Research Section in Singapore. 


\section{(e) Association of South-east Asian States (ASA)}

Although "co-operation" is a natural and instinctive inclination of human behaviour, intercourse between States within the Asian Pacific Community was not possible until after Bandung. Once given the opportunity it would not be unnatural for neighbouring States to foster closer co-operation in economic as well as in other fields. While regional cooperation in Europe was free and unencumbered, Asia had for centuries been a continent of war-torn pieces of territorial possessions, a hunting ground for outside powers without being altogether free from intraregional struggles. The earliest form of co-operation and association in the region was bilateral between two like-minded neighbours. Such were the cases between Thailand and the Federation of Malaya, between Burma and Thailand and between Pakistan and Indonesia. It was not until 1961 that a sub-regional grouping could be formed from a series of closely knit bilateral co-operation. The formation of ASA, the Association of South-east Asian States, was the first regional co-operation of like-minded nations in the economic, social and cultural fields. Malaysia, the Philippines and Thailand were founding members of ASA, which was the predecessor of ASEAN, a larger Association with which it was finally merged. A number of existing ASA projects have become ASEAN.

\subsubsection{The labour pain preceding the birth of ASEAN}

The two years following the celebration of the tenth anniversary of the Bandung Conference in 1965 were trying times not only for the unsuccessful attempts by Algeria to convene a Second Asian-African Conference in Algiers, but more particularly for the States that were to become partners in the ASEAN venture. Indonesia, under President SUKARNo and Foreign Minister SUBANDRIO, was outwardly very powerful, especially within the Non-Aligned Group, and was flirting with Socialist countries. The PKI (Partai Komunis Indonesia) was the largest Communist Party in the world outside of the USSR An axis was formed linking together Pyong Yang (North Korea), Peking (China), Hanoi (North Vietnam), Phnom Penh (Cambodia) and Jakarta (Indonesia. There was troubled water everywhere from Hanoi, Vientiane, Pnom Penh through Jakarta.

At this juncture, the United Kingdom, for reasons of her own, decided to create Malaysia by adding the territories of Sarawak and Sabah to the Federation of Malaya. Malaysia was born as an extension of an existing State. SUKARNO was not pleased with Greater Malaysia. As if to add insult to injury, the United Nations not only recognised Malaysia as successor State to the Malay Federation but also the new State was elected member of the Security Council. SUBANDRIO adopted the policy of "Konfrontasi" or 
"Confrontation against Malaysia". Before the latter took its seat in the Security Council, Indonesia withdrew from the United Nations altogether and intensified her "Confrontation" policy, opposing Malaysia's admission to the Asian-African Conference in Algeria. Paratroopers were dropped inside Malaysian territory in Sarawak and Malacca, and there were sporadic disturbances in Singapore.

The Philippines also protested against the addition of Sabah to Malaysia as it had a long-standing claim to Sabah traceable back to the Sultanate of Sulu. The discord between the Philippines and Malaysia disrupted the progress of ASA which during this critical period continued to subsist in a state of suspended animation.

The Philippines, supported by Japan, offered to resolve the problem through the creation of another association called MAPHILINDO, consisting of Malaysia, the Philippines and Indonesia. The proposal never got off the ground since it was tainted with religious overtones. Meanwhile, Thailand was requested to look after the interests of Malaysia in Indonesia and the Philippines, and vice-versa.

A break occurred when Colonel UNTUNG staged an unsuccessful coup d'Etat in Indonesia. A number of Indonesian generals in active service were captured, tortured, assassinated and mutilated. Those that escaped capture headed a new government under General Suharto and from that time on, the tide turned in favour of regional co-operation upon the sudden disavowal of the policy of confrontation. Thailand, through her skilled Foreign Minister, Dr. THANAT KHOMAN, managed to provide good offices which not only restored diplomatic relations among the nations of the region but also inspired regional confidence among all leaders concerned.

Normalisation of relations meant revitalisation if not indeed resuscitation of ASA which resumed the activities it had suspended since the advent of Greater Malaysia. Indonesia was invited to attend the Third ASPAC Ministerial Meeting in Kawana, Japan, and sent an Ambassador ${ }^{10}$ as its observer. Singapore seceded from Malaysia and virtually remained an informal member of ASA.

Thailand, perceiving the precious moment, swiftly took the lead to propose a new regional organisation for economic co-operation which would include the ASA countries and Indonesia. Singapore was privy to the negotiation. The draft proposal was first discussed between Thailand with the mandate from other ASA members and Indonesia. It would not seem right to ask Indonesia, by far the largest country, to join the existing association, ASA. Thus instead of enlarging ASA to include Indonesia, ASA was merged

10. General Roєкміто was then Indonesian ambassador to Japan. 
into a new organisation called: Association of South-East Asian Nations (ASEAN).

\subsection{The Principles and Objectives of ASEAN}

Born with intense labour pain, ASEAN had its traumatic experience upon delivery. Before its birth it was nurtured in Thailand's soil with utmost pre-natal care. Its draft constituent instrument was discussed at Laem Taen, Bangsaen. Finally, the Press Communiqué released in Bangkok following the meeting of Ministers who signed the Bangkok Declaration on 8 August 1967, launched into orbit the infant association called ASEAN.

The reasons which inspired the member States to create ASEAN are contained in the preamble of the Bangkok Declaration which includes the following:

The need to strengthen further the existing bonds of regional solidarity and co-operation and the existence of mutual interests and common problems;

The desire to establish a firm foundation for common action to promote regional co-operation in South-East Asia in the spirit of equality and partnership and thereby contribute towards peace, progress and prosperity in the region;

The awareness that the cherished ideals of peace, freedom, social justice and economic well-being are best attained by fostering good understanding, good neighbourliness and meaningful co-operation among the countries of the region already bound together by ties of history and culture;

The primary responsibility shared by the countries of South-East Asia for strengthening the economic and social stability of the region and ensuring their peaceful and progressive national development;

The determination of the countries of the region to ensure their stability and security from external interference in any form or manifestation in order to preserve their national identities in accordance with the ideals and aspirations of their peoples;

The affirmation that all foreign bases are temporary and remain only with the expressed concurrence of the countries concerned and are not intended to be used directly or indirectly to subvert the national independence and freedom of States in the area or prejudice the orderly processes of their national development.

The aims and purposes of the Association are:

1. To accelerate the economic growth, social progress and cultural development in the region through joint endeavours in the spirit 
of equality and partnership in order to strengthen the foundation for a prosperous and peaceful community of South-East Asian Nations;

2. To promote regional peace and stability through abiding respect for justice and the rule of law in the relationship among countries of the region and adherence to the principles of the United Nations Charter;

3 . To promote active collaboration and mutual assistance on matters of common interest in the economic, social, cultural, technical, scientific and administrative fields;

4. To provide assistance to each other in the form of training and research facilities in the educational, professional, technical and administrative spheres;

5. To collaborate more effectively for the greater utilisation of their agriculture and industries, the expansion of their trade, including the study of the problems of the international commodity trade, the improvement of their transportation and communication facilities and the raising of the living standards of their peoples;

6. To promote South-East Asian studies;

7. To maintain close and beneficial co-operation with existing international and regional organisations with similar aims and purposes, and explore all avenues of even closer co-operation among themselves.

These aims and purposes have been vigorously pursued by ASEAN from the day it was born. The emphasis is unmistakably placed on equal partnership which underlies all ASEAN undertakings and activities to date.

\section{COLLECTIVE ASEAN ENDEAVOURS}

There are several ways of classifying activities of a regional organisation for economic co-operation. ASEAN activities cover at lease two principal areas: (1) Intra-ASEAN activities pertaining mainly, if not exclusively, to mutual co-operation in trade, investment or tourism; and (2) ASEAN relations of active co-operation with the outside world, or with non-ASEAN countries, which in turn could be further subdivided into relations with immediate neighbours, with Pacific Rim partners and with other nations from other regions of the world such as West and Central Asia, Africa, Latin America and Europe. 


\subsection{Intra-Asian Co-operation}

It may be beyond the scope of a study of ASEAN activities to attempt even a simple outline of the organisational aspects of the Association which truly deserves a separate treatment showing a gradual progress from a modest start with multiple national secretariats to the establishment of a common general secretariat with a regular annual budget and an international staff. Suffice it to state that the Association has been growing from strength to strength with regard to its internal organisation and staffing pattern and the funds provided by member States. ASEAN meets at various levels: the Summit, the Annual Ministerial Meetings, the Economic Ministers' Meetings, the Meetings of other Ministers, of Senior Officials, of the Standing Committee and the meetings of various permanent and $a d$ hoc committees. The private sector also organised their ASEAN meetings, such as the ASEAN Chambers of Commerce and Industry which had met even before the official launching of ASEAN. A Special Co-ordinating Committee was also established to streamline pending projects and minimize overlapping activities of various committees and bodies.

At various levels of official and private-sector meetings, the Association has undertaken a great number of ASEAN projects. With leaps and bounds, ASEAN has expanded or contracted in response to the need to concentrate on the development of certain areas requiring special attention. Thus, at the outset ASEAN inherited all ASA programs and pending projects and added a considerable number to the list of possible areas of co-operation among its members. An ASEAN study was conducted with the assistance of a team of technical experts attributable to the United Nations which did help member States in deciding the future direction of ASEAN co-operation. ${ }^{11}$

ASEAN activities covered a great many areas of experimentation which subsequently either flourished or faded into oblivion. In all of the fields listed in its objectives, ASEAN has ventured with greater or lesser degree of success. Specifically, ASEAN has reached several important agreements and concluded significant and far-reaching treaties in various forms, ranging from the Treaty of Amity and Co-operation in South-East Asia of 24 February 1976 and the Protocol Amending the Treaty, following the Manila Declaration of 15 December 1987; the Kuala Lumpur Declaration of 27 November 1971 on the Zone of Peace, Freedom and Neutrality; the Declaration of ASEAN Concord following the Bali Summit of 24 June 1976; the Agreement for the Establishment of a Fund for ASEAN on 17 December 1969 and the Agreement for the Establishment of the ASEAN Secretariat of

11. See infra, n. 46. 
24 February 1975. In the substantive areas of economic co-operation, special attention may be paid to the Agreement on ASEAN Preferential Trading Arrangements of 16 February 1977 which has since been in force with increasing measure of success, the Basic Agreement on ASEAN Industrial Projects of 6 March 1980 in order to co-operate in establishing large-scale ASEAN Industrial Projects, particularly to meet regional requirements for essential products (utilising available resources in the region and contributing to the increase in food production), and the Basic Agreement on ASEAN Industrial Complementation of 18 June 1981.

From the very start, ASEAN leaders never had the illusion that ASEAN would become a Common Market. They fully realised the diversities and contrasts in their countries' economic structures and national legal frameworks. Even a more modest goal like a Free Trade Area appeared to be out of reach for reasons of existing divergencies in the fiscal structures and policies. But that should not deter ASEAN determination to continue to cooperate. The programme closest to the establishment of a Free Trade Area was the adoption of Preferential Trading Arrangements which ASEAN in fact launched. It also intensified its tightening efforts to encourage intraASEAN trade by creating complementarity where none had existed in the past. $^{12}$

Intra-ASEAN activities may be grouped under a variety of headings, notably among which include co-operation, co-ordination and harmonisation in the fields that appear of practical importance to the peoples and Governments of ASEAN.

\subsubsection{Economic Co-operation}

This is contained in the aims and purposes as specified in the ASEAN Declaration. As such, economic co-operation requires primary attention. It may take almost any form, but must be practical and mutually beneficial consistent with the underlying concept of "equal partnership". ASEAN leaders have been pragmatic in their approach. Every conceivable measure having been thoroughly examined, the common economic policies appear now to include the promotion of intra-ASEAN trade, joint-venture in industrial investment and development and intra-ASEAN tourism.

12. As will be seen in the pages that follow, no formal proposal was made by any member State before 1991 for ASEAN to become a free trade association. A modest practical start began with the transfer of existing ASA projects to ASEAN, and proposals for ASEAN projects were assigned by the Second ASEAN Ministerial Meeting in Jakarta, 16-18 August 1968, for further study by the ASEAN Standing Committee and the ASEAN Secretary-General. This is borne out in the joint communiques of subsequent Ministerial Meetings. Even reduction of tariff barriers under the ASEAN Preferential Trading Agreements (PTA) has taken many years to bear some fruits. See also infra, n. 13. 


\section{(a) Promotion of Intra-ASEAN Trade}

This policy is basically sound but requires sufficient incentives for increasing interchanges of commodities among the ASEAN countries. There should be complementarity of products, which in the agricultural field appear to be difficult to achieve. In the newly created industries, however, co-ordination and harmonisation could create a more united ASEAN market with evenly distributed suppliers from various parts of the region. Some improvements are visible after the latest across-the-board reduction of tariff in the form of ASEAN Preferential Trading Agreements ${ }^{13}$ designed to encourage trading within the region. The success might, of course, be regarded as minimal compared to the growth of intra-Community trade within the European Economic Community.

\section{(b) Promotion of Intra-ASEAN Investments}

This policy requires the co-operation of ASEAN governments as well as that of the private sectors within the region. Joint-ventures have taken place in various industrial investments and developments and there appears to have been a freer flow of goods, services and capitals within ASEAN as a result of various agreements concluded by ASEAN countries. Relaxation of immigration regulations, exemptions from visa requirements, exemptions from fiscal restrictions and partial exemptions from duties and other forms of taxation have encouraged the movement of skilled and unskilled labour forces from one ASEAN country to another.

\section{(c) Promotion in Intra-ASEAN Tourism}

This is partly economic co-operation and partly cultural exchange. Movements of people, not only investors and traders but also visitors and tourists, have been encouraged across ASEAN national frontiers. Facilities have been established at border posts to allow crossing with only border passes, while travel by air hardly requires advanced visas for ASEAN nationals. Although this is nowhere close to the facilities afforded by a member of the European Community to other nations of the Community, the facilities granted have eased, if not accelerated, the movement of tourists within the ASEAN region. Not unlike the facilities available within the European Community, ASEAN has rotated their "Visit ASEAN Year", highlighting places of interest in each of the ASEAN nations. At the same time, package tours of all kinds have been available to enable tourists, intra-

13. This is an area that requires a separate in-depth study. An enquiry may begin with the practice of ASEAN since its adoption of the Agreement on ASEAN Preferential Trading Arrangements of 16 February 1977, see Multilateral Treaties between ASEAN Countries (ASEAN Law Series, Butterworth, hereafter: ASEAN Multilateral Treaties), pp.113-119, 120-123, Annex I: Rules of Origin for the ASEAN Preferential Trading Arrangements. 
ASEAN as well as extra-ASEAN tourists, to visit one or two other beauty spots of another ASEAN country without extra cost.

\subsubsection{Co-operation in infra-structural development planning}

ASEAN activities classified as co-operation in infra-structural development planning cover very wide areas of facilitating intra-ASEAN transportation and communications. This is not at all surprising as an instinctive reaction to the separation to which member States of ASEAN had been subjected prior to Bandung. Now that each has been liberated from the yoke of ex-communication with the other ASEAN member States, the way is open for restructuring of means of mutual contacts and of continuance of direct and uninterrupted communications.

\section{a. Promotion of Telecommunication}

Every possible means of intra-ASEAN telecommunication has been considered and structured to permit direct communication links such as by submarine cables across the sea-bed connecting all the member States separated by any expanse of water. Satellite communications have also been established, as many of ASEAN ground-stations lie within direct reach of satellites in geostationary orbits. ${ }^{14}$ Ground stations have been established in several spots within ASEAN countries. Thus, many ASEAN countries share the services of Indonesia's Palapa Communication Satellite for their respective internal communications. ${ }^{15}$ Television broadcast can also be relayed through satellite communication channels. Remote sensing is another possible use of artificial satellites to survey and manage natural resources on earth.

\section{b. Promotion of Safety and Security at Sea}

ASEAN States are without exception sea-faring nations. With the exception of Singapore which is a geographically disadvantaged State, other ASEAN nations have very extended coastlines. In fact, Indonesia and the Philippines are archipelagic State ${ }^{16}$ with archipelagic waters and sea-lanes. To ensure the safety and security at sea, several measures have

14. A "geostationary" orbit is a narrow orbital ring around the earth appromately 22,300 miles $(35,800 \mathrm{~km}$.) above the equator. Satellites in these orbits rotate in the same directional movement and at the same speed as the earth rotation, thereby maintaining their locations in space on approximately the same spots.

15. See, in particular, PrIYATNA ABDURRASYID, "Developing Countries and Use of the Geostationary Orbit", Proceedings of the Thirteenth Colloquium on the Law of Outer Space (1987, pp.375, 379-80).

16. Indonesia was the first to propose the concept of "archipelagic State" as early as 1957 during UNCLOS I. The Philippines also claimed "historic waters". Under the UN Convention on the Law of the Sea 1982, Indonesia and the Philippines were both recognised as "Archipelagic States" for the purpose of a new law of the sea. 
been adopted to facilitate the search for ships in distress and rescue of survivors of ship accidents. ${ }^{17}$ The benefits of this agreement are not limited to ASEAN flags. The duties and obligations have been undertaken by ASEAN member States to provide such measures of assistance as may be necessitated by the circumstances to ships in distress in their territories and neighbouring seas as they may find practicable. In this connection, Search and Rescue (SAR) required the identification and designation of Rescue Co-ordination Centre (RCC) and Local Rescue Co-ordination Centres (LRCC) in all ASEAN member countries.

By the same token, since the oil spill accident befalling the Japanese tanker Showa Maru in the mid-seventies, Malaysia, Singapore and Indonesia, the three ASEAN riparians of the Malacca Strait ${ }^{18}$ have established a traffic separation scheme to ensure the safety of navigation through the Malacca Strait. This might have spurred some excitement and even opposition from the protagonists of "freedom of navigation" in the context of an "international strait". The controversy was pre-empted by the strait States' submission of their traffic separation scheme to the Inter-Maritime Consultative Organisation (now IMO) for approval. Thus, ASEAN nations in practice, as well as in law, continue to exercise effective and undisputed control over the passage through the Malacca Strait, primarily an intra-ASEAN affair, but with far-reaching strategic implications for ASEAN as a whole. It should be added that while merchant shipping is a relatively novel enterprise in some ASEAN countries such as Thailand, Malaysia and Indonesia, it has long played an important role in the external trade of Singapore and the Philippines. ASEAN countries have spared no effort to co-operation in the field of intra-regional shipping. ${ }^{19}$

17. See, in particular, the Agreement for the Facilitation of Search for Ships in Distress and Rescue of Survivors of Ship Accidents, 15 May 1975 (citing Chapter V: Salety of Life at Sea, annex to the International Convention for the Safety of Life at Sea), in: ASEAN Multilateral Treaties, pp.97-101, with annexes.

18. In February 1975, the Showa Maru, a Japanese super-tanker of 237,698 deadweight tons, ran aground in the Malacca-Singapore Straits, south of Singapore, causing three out of the twelve tanks to split and more than 3,380 tonnes of crude oil spilled into the waters. Malaysia claimed US $\$ 10$ million damages from the owners of the tanker for the cost of cleaning up and pollution damage to the beaches and the fish culture; Singapore claimed US $\$ 1.6$ million for the expenses of clearing up the oil slick, and Indonesia claimed over US $\$ 15$ million for antipollution measures and ecological damage to the marine environment. Several collisions occured in the straits in June 1985 and later in 1976 with the result that the strait States had to take more stringent measures, such as devising the traffic separation scheme to ensure the safety of navigation. For a more detailed study of the régime of the straits, see K.L. KOH, Straits in International Navigation, Contemporary Issues (Oceana, 1982) pp.78-82.

19. Thus, an integrated Work Programme on Shipping was drawn up for the period 1982-1986 (WWS) to co-ordinate implementation of ASEAN common policy in shipping as enunciated in the Resolution on Shipping. This Resolution aimed at attaining greater efficiency and economy in the carriage of ASEAN trade by promoting and strengthening self-reliance and co-operation in shipping.. 


\section{c. Promotion of Safety and Security in Air-Traffic}

Although relatively new-comers to the business of carrying trade by air, ASEAN countries have become regional and even global carriers. Without exception, every member State has its own international and domestic airlines. Most ASEAN airlines have started with some external technical co-operation, but are now completely independent of outside assistance and are operational on their own strength. Among them cooperation has begun on pooling of services, traffic-sharing and mutual promotion. A multilateral Agreement was concluded granting commercial rights of non-scheduled air-services among the ASEAN nations in $1971 .^{20}$ These rights are initially limited to third and fourth freedom traffic. ${ }^{21}$

An agreement similar to the one on maritime navigation was concluded by ASEAN States as early as 14 April 1972 in Singapore, for the facilitation of search for aircraft in distress and rescue of survivors of aircraft accidents. $^{22}$

The ASEAN Committee on Transportation and Communications has adopted various projects. Among these activities should be mentioned the publications on climatic data and the AIREP (Air-Reports) programme which have been compiled on a routine basis by the meteorological services of individual ASEAN countries. These two projects entail elaborate efforts of data processing, analysis and the production of uniform presentation using the latest scientific techniques. Greater skills have thus been developed in the collation and treatment of climatological information and air-reports in each ASEAN country. ${ }^{23}$

The ASEAN International Airport Association was established in 1982 to develop regional co-operation among ASEAN international airports on airport development, operation and management. Centres of excellence for meteorological training and for aviation security training were set up in the Philippines and Malaysia respectively. ${ }^{24}$

\subsubsection{Intensification of cultural exchanges and development}

It has become apparent that out of the apparent differences in national

\footnotetext{
20. See Multilateral Agreement on Commercial Rights of NonScheduled Air Services among the Association of South-East Asian Nations, 13 March 1971, in ASEAN Multilateral Treaties, pp.86-90, with the annex, in which several airports have been designated for the purpose.

21. Article 2 (1), see ibid. at p.87.

22. See Agreement on the Facilitation of Search of Aircraft in Distress and Rescue of Survivors of Aircraft Accident, 14 April 1971, ibid., pp.92-96.

23. See Statement by Chairman of the Standing Committee, 15th ASEAN Ministerial meeting, Singapore, 14-18 June 1982, pp.36-37.

24. See the Report of the Committee on Transport and Communications, Annual Report of the ASEAN Standing Committee, 1981-82 (published by ASEAN Secretariat) pp.34-35.
} 
history, ASEAN countries retain their common cultural heritage from ancient times before their contact with the Western world. Although each of the member States of ASEAN is a pluralistic society with varying components of different ethnic groups, the variations in the composition of the population appear to follow a similar pattern with several common languages and basic religions that are commonly practiced in all the countries of the region. Linguistically, Malay is principally used in at least three or four out of the six ASEAN States and is also the language of a minority group in the other two countries. Religiously, Islam is prevalent among the Malay-speaking population of ASEAN although Buddhism is practiced in Thailand and among the Chinese in Singapore, and there are Buddhist temples in Malaysia as well as in Java. Catholicism is predominant in the Philippines but widely followed in other ASEAN countries where other Christian sects are also known. Against a similar background of diversities of their pluriform societies, the member countries of ASEAN have been able to establish a common identity through their community of national interests. Thus, although English is only one of the official languages of the Philippines, Malaysia and Singapore, the ASEAN States have resorted to English as the official language among themselves.

a. Co-operation in Social Development.

ASEAN is committed to intensify active co-operation in the field of social development with emphasis on the well-being of the low-income groups and of the rural population, through the expansion of opportunities for productive employment with fair remuneration, and on development efforts relating to women and youth. Intra-ASEAN co-operation to meet the challenges of population growth and, where possible to formulate new strategies in collaboration with appropriate international agencies has been further intensified and expanded. Co-operation in the social field is further intensified in regard to the prevention and eradication of the abuse of narcotics and the illegal trafficking of drugs. ${ }^{25}$

\section{b. Co-operation in Cultural and Mass Media Activities}

The study of ASEAN as well as its member States and their national languages has been introduced as part of the curricula of schools and other institutions of learning in the member States. ASEAN countries have firmly supported the exchange of scholars, writers, artists and teachers to enable them to play an active role in fostering a sense of regional identity and fellowship. Not only are national and regional resilience being encouraged within ASEAN nations, the community is now also developing a collective will, an ASEAN consciousness. South-East Asian studies have been promot-

25. As evidenced in the Declaration of ASEAN Concord on 24 February 1976, ASEAN Multilateral Treaties, pp.24-29. 
ed through closer collaboration among national institutions. Several cultural projects are pursued on a continuing basis under the auspices of the ASEAN Committee on Culture and Information, ${ }^{26}$ and an ASEAN Cultural Fund has been established in $1978 .{ }^{27}$ Pursuant to an earlier Agreement for the Promotion of Co-operation in Mass Media and Cultural Activities $1969,{ }^{28}$ ASEAN countries have been promoting mass media activities by broadcasting regular programmes to reflect the aims, purposes and activities of ASEAN by radio and television, by organising film festivals, exchange of film artists and undertaking of joint film production, and by organising seminars, symposia and other activities on mass media.

\subsubsection{Co-operation on Food, Agriculture and Forestry}

\section{(a) Common Agricultural Policies}

Member States co-operate closely to ensure self-sufficiency in basic food commodities. Common agricultural policies have been developed in a manner not unlike the European Economic Community in its initial stages, and there has been extensive pooling of research and technology.

(b) The ASEAN Food Security Project (AFSP)

This has been one of the most important and successful project and was adopted by ASEAN in 1981. A good information and early warning system has been implemented. An Emergency Rice Reserve, in line with the FAO Food Reserve Programme, has been set at 50,000 tons with contributions from each member country. Its size is kept under review by the ASEAN Agricultural Development Planning Centre (ADPC). This Centre also plays a role in the case of possible inclusion of other basic food commodities in the Reserve. $^{29}$

\section{(c) Production and Supply of Fertilizers, Pesticides and other} Agricultural Inputs.

At the directions of the Committee on Food, Agriculture and Forestry, the ASEAN Agricultural and Forestry Ministers met and assigned the Co-ordinating Group on Crops to undertake a study on the supply and demand

26. See the Declaration of ASEAN Concord, ibid., p.27. Performances, exhibitions and related cultural activities include, inter alia, an ASEAN travelling exhibition of paintings and photographs in ASEAN countries, an exhibition of photographs on ASEAN cultural heritage, radio and TV exchange programmes, performances by ASEAN artists, ASEAN song festivals, ASEAN film frstivals, ASEAN film weeks, the production and distribution of ASEAN prints and audio visual materials, ASEAN traditional games and sports.

27. Ibid, at pp.124-129.

28. Ibid., at pp.82-85.

29. See, e.g., ASEAN Agreement on Food Security Reserve, 4 October 1979, ASEAN Multilateral Treaties, pp.138-145. 
of non-urea fertilizer in ASEAN. A pre-feasibility study was prepared with the help of the United States Trade and Development Programme. ${ }^{30}$

(d) ASEAN Quarantine Ring.

ASEAN Plant Quarantine Centre and Training Institute (PLANTD provides a focal-pointed co-ordinating mechanism to improve all plant quarantine activities through training, research and information exchange. A proposed ASEAN Common Regional Animal Quarantine Centre (ACRAQC) was, however, replaced by strengthening of ASEAN national quarantine stations. ${ }^{31}$

\section{(e) Food Handling}

The ASEAN Food Handling Bureau serves as the main communication link between the Sub-Committee on Food Handling and its various working groups on grains, livestock, fish and horticulture. The co-operation covers several aspects of the processing, packing, transportation and quality control of grains, vegetables, fruit, horticultural produce, livestock and fish as well as man-power development and abattoir designing. It is also aimed to cut cost harvest spoilage and wastage in the ASEAN region.

(f) Co-operation in Forestry

The Jakarta Consensus on ASEAN Tropical Forestry sets out a comprehensive programme of co-operation that covers the adoption of a common forestry policy, the promotion of technical co-operation, the establishment of a suitable institution, co-operation in timber-trade, and an ASEAN common stand on international issues. Four ad hoc Export Groups were set up: Forestry resources conservation and management, timber production and processing, timber marketing and trade and forest environment and wildlife were assigned to the Groups led by, respectively, Malaysia, the Philippines, Thailand and Indonesia. ${ }^{32}$

\section{(g) New Proposals}

Several projects have been in the pipeline for possible third country funding. These include the ASEAN Agricultural Project Formulation, the ASEAN Fish Quarantine Project and the ASEAN Food Handling Programme.

30. See ibid., Agreements No. 12 (Indonesia) and No. 13 (Malaysia), pp.164-169 and pp.170175.

31. See ASEAN Declaration to Eradicate Foot and Mouth Diseases, ibid., pp.54-56, and ASEAN Delcaration on Specific Animal Diseases Free Zone, ibid., pp.57-59. The national quarantine stations are at Kepala Jernih (Indonesia), Kuantan (Malaysia), Alabang (Philippines), Jurong (Singapore) and Bangkok (Thailand).

32. See Manila Declaration on the ASEAN Environment, ibid., pp.50-53. 


\subsubsection{Co-operation in Industrial Projects, Minerals and Energy}

(a) ASEAN Industrial Projects (AIP)

Significant ASEAN industrial projects have been planned and undertaken, including the ASEAN UREA Project (Indonesia), ASEAN UREA Project (Malaysia), ASEAN Copper Fabrication Project (Philippines), and ASEAN Rock Salt-soda Ash Project (Thailand). These AIPs have been allocated to host country proponents with each of the other ASEAN member countries having an option to own a minimum of 10 per cent of equity. A substantial margin of preferences have been extended to products of the first five AIPs for the first five years from the date of commercial operation. The Indonesian project was the first to be operational.

(b) ASEAN Industrial Complementation (AIC)

Bilateral negotiations on non-tariff preferences were initiated even before the Basic Agreement came into force. The Basic Agreement was concluded in $1981^{33}$ when the First Package of Existing Automotive Components under the AIC Scheme was formally implemented. A Second Package of New Automotive Components has been adopted. ${ }^{34}$

(c) ASEAN Industrial Joint-Ventures (AIJVS)

These are private sector equivalents enjoying exclusive privileges similar to AIC products. There was also the question of the extent of non-ASEAN equity participation and the nature of preferential trading arrangements to be thrashed out. Many of these ventures are now operational.

(d) ASEAN Co-operation on Minerals

Various proposals have been put into effect within the ASEAN Minerals Co-operation Plan, including:

(i) beneficiation and marketing of kaolin;

(ii) beneficiation of low grade barite; and

(iii) the establishment of an ASEAN Training Centre for Mine Safety and Health.

(e) ASEAN Co-operation on Energy

A Coal Information Centre was created as part of the ASEAN Co-operation on Energy.

(f) ASEAN Co-operation in Power Utilities/Automatics

Working groups have been established each of the following projects:

33. Basic Agreement on ASEAN Iridustrial Complementation, 18 June 1981, ibid., pp.195-200.

34. The Second Package includes the following disbribution: Indonesia: steering systems; Malaysia: headlights for motor vehicles; ['hilippines: heavy duty rear axles for commercial vehicles; Singapore: fuel injection pumps; Thailand: carburettors. 
microhydro development; computer applications; interconnection; research, development and engineering; training; geothermal development; nuclear power for electric power generation; rural and urban electrification; standardisation and the development of an electric power information centre.

\subsubsection{Co-operation in Finance and Banking}

Extensive co-operation exists among ASEAN countries on matters relating to finance and banking. The following projects now in operation need be mentioned:

a. ASEAN Bankers Acceptance (ABA), resulting from the meeting of an Expert Group of ASEAN Central Banks and Monetary Authorities.

b. Customs and Insurance Matters: An ASEAN Customs Code of Conduct was adopted, covering basic principles and standards on customs valuation, classification, techniques and related matters. ASEAN insurance commissioners have proposed measures for cooperation in the field of reinsurance, marine cargo insurance and export credit insurance.

c. ASEAN Swap Arrangement, designed to alleviate temporary shortage of international liquidity among member countries, providing each member country with a credit line of US\$ 80 million.

d. Access to capital markets: Various projects have been implemented and new avenues of promise pursued, including access to capital markets in the EEC, in the United States, Japan and West Asia.

e. Avoidance of double taxation: Continuing progress has been achieved as between member States.

\subsubsection{Co-operation in Science and Technology}

ASEAN co-operation in science and technology covers extensive grounds, many of which have been considered under other headings. Suffice it to mention that in addition there has been active co-operation within ASEAN in the following projects: (a) ASEAN Trust Fund, to finance an ASEAN Plan of Action on Science and Technology; (b) Management and Utilisation of Food-waste Materials; (c) Food Technology Research and Development Project; (d) Non-conventional Energy Research; (e) Action Plan on the East-Asian Seas; (f) ASEAN Co-operative Programme on Marine Sciences; (g) ASEAN Co-operation in the Field of Corrosion; (h) ASEAN Co-operation in Materials Processing; and (i) Science and Technology Infra- 
structure Development.

\subsubsection{Asian Co-operation in Political and Security Matters}

Without collective political will, ASEAN solidarity could not endure the harsh realities of regional economic co-operation. Without political consciousness and national resilience, ASEAN could not weather and survive the storm of dissensions left over by departing external powers. Co-operation in the political field is absolutely vital to the very existence of ASEAN as a regional association. External and intra-regional security is the lifeline of the organisation. Co-operation in the six areas outlined above inevitably and irreversibly led to ASEAN co-operation in political and security matters. The transition from economics to politics was only a matter of time. With ASEAN, as it has been with the EEC, the process has taken no more than a decade or a cycle of twelve years to reach the transformation ASEAN now enjoys, notwithstanding the absence of a permanent ASEAN military force to ensure the collective defence and maintain the peace and security of the region. Military co-operation exists in practice on a bilateral rather than regional basis. Joint border patrols are periodically in operation between Thailand and Malaysia as well as between Malaysia and Indonesia. Thai-Indonesian combined forces have been engaged in military and naval exercises as well as in active combat operation, as on one occasion in the rescue operation of a hijacked Garuda Indonesian aircraft in Bangkok in the early eighties.

A number of areas of political co-operation deserve mention:

(a) The Practice of Regional Tolerance

To tolerate and accept the existing differences within ASEAN was the first step towards closer understanding and deeper appreciation of one another within the ASEAN community. To a large extent the ASEAN studies and cultural exchange programmes have done much to foster ASEAN consciousness, resilience and solidarity. The expressions "A.SEAN Consciousness", "ASEAN Solidarity" and "ASEAN Resilience" have become "catch phrases" in the day-to-day vocabulary of ASEAN parlance.

For "ASEAN Consciousness", attention has been increasingly concentrated on the youth and grassroots of the population, in the human resources and their social and cultural developments, to instill an awareness of "ASEAN" in every national of a member State.

"ASEAN Solidarity" requires little additional explanation. It implies that ASEAN nations will stick together, will vote together after close consultations, and at times, in spite of differences that may exist in their respective positions as in the Law of the Sea, a dissenter would remain silent or ab- 
stain rather than express pro forma dissent.

"ASEAN Resilience" has acquired special meanings. For instance, para. 9 of the Joint Communique of the Fifth ASEAN Ministerial Meeting in Singapore, 13-14 April 1972, reads, in part, "They [the ASEAN Ministers] agreed that for greater self-reliance and more effective co-operation, a coordinated and well-planned strategy was needed on the national as well as regional levels. It was necessary for member countries to develop national resilience which would enable them to face the present changes and challenges of the future with great confidence." (emphasis added). The meaning of "national resilience" in the ASEAN phraseology is thus much clarified. Again, at the Seventh ASEAN Ministerial Meeting in Jakarta on 7 May 1974, para. 5 of the Joint Communiqué carried a statement by President Soeharto who expressed his pleasure to note "that ASEAN member countries had been successfully directing their efforts to the establishment of economic stabilisation and the furtherance of development in their respective countries which would both give substance to national independence of each member country and contribute to the joint efforts of strengthening of the regional resilience, so much needed to put ASEAN in a better position and increasingly gain the recognition and respect of the major powers." (emphasis added).

Finally, another use of "resilience" as a term of endearment in the ASEAN context can be found in para. 46 of the Joint Communique of the Nineteenth Ministerial Meeting in Manila, 23-28 June 1986, as follows:

"The Foreign Ministers stressed the imperative of tapping ASEAN's vast potential for regional economic co-operation to ensure ASEAN dynamism and resilience in the face of challenges to its development and growth ..." (emphasis added).

A new phrase is coined "ASEAN dynamism" as part and parcel of "ASEAN resilience", a term frequently used to indicate ASEAN strength and capacity for self-improvements and adaptation to the prevailing conditions of the world, be it world market, world politics or world peace.

(b) The Principles of Non-Use of Force and GoodNeighbourliness

The practice by ASEAN of non-use of force and good-neighbourliness towards one another within the region, time-honoured principles traceable back to Bandung and to the Charter of the United Nations, have contributed to the burial of the hatchet and the shelving of bilateral and sub-regional differences. The ASEAN spirit of give-and-take must replace national superiority, as equality of partnership has replaced domination and hegemony in the region. It was in this broader perspective and for longer term peace and security of the region that the nations of ASEAN have been able to put 
aside whatever differences might have existed or continued to subsist among themselves.

(c) The Creation of ASEAN Mechanism for Conflict Resolution

As a corollary to the principles of non-use of force and non-interference or non-intervention in internal affairs, a machinery has been set up to facilitate the settlement of disputes that require attention. The Treaty of Amity and Co-operation in South-East Asia ${ }^{35}$ concluded on 24 February 1976, following the Bali Summit, contains provisions requiring ASEAN member States to refrain from the threat or use of force and at all time to settle disputes among themselves through friendly negotiations, failing which regional processes are available for settlement by a High Council comprising a representative at ministerial level from each of the ASEAN member States. The High Council is designed "to take cognizance of the existence of disputes or situations likely to disturb regional peace and harmony". Appropriate means of settlement by the Council include good offices, mediation, inquiry and conciliation. A committee may be set up for this purpose and the High Council may also recommend appropriate measures for the prevention of deterioration of the dispute or situation. It should be noted that by the Protocol Amending the Treaty of Amity and Co-operation in SouthEast Asia adopted on 15 December 1987 following the Manila Summit ${ }^{36}, \mathrm{Ar}$ ticle 14 of the Treaty may also "apply to any of the States outside South-East Asia which have acceded to the Treaty, only in cases where that State is directly involved in the dispute to be settled through the regional processes."

\section{(d) Adoption of an Intra-ASEAN Standard for the Promotion and Protection of Regional Investments}

Within the Group of 77 , each of the ASEAN nations has followed the majority view approaching consensus of opinion with regard to the measure of compensation in the event of expropriation of foreign investment in general. A standard not dissimilar from that proposed by Secretary Hull in the Mexican treatment of American investments appears to have been adopted for ASEAN investments within ASEAN. Thus, Article VI (1) of the ASEAN Agreement for the Promotion and Protection of Investments of 15 December $1987,{ }^{37}$ provides:

"Investments of national and companies of any Contracting Party shall not be subject to expropriation or nationalisation or any measure equivalent

35. See, in particular, Articles 13, 14 and 15, text in ASEAN Multilateral Treaties, pp.67-74. 36. See Article 1 of the Protocol of December 1987, 27 ILM (1988), pp.597-624, at p.609. 37. Ibid., at p.613. See also M. SORNARAJAH, "The New International Economic Order, Investment Treaties and Foreign Investment Laws in ASEAN", 27 Malaya Law Review (1985), pp.440458. 
thereto, except for public use, or public purpose, or in the public interest and under due process of law, on a non-discriminatory basis and upon payment of adequate compensation. Such compensation shall amount to the market value of the investment affected immediately before the measure of dispossession became public knowledge, and it shall be freely transferable in freely-usable currencies from the host country. The compensation shall be settled and paid without undue delay..."

The treatment thus accorded intra-ASEAN investments appears therefore to be more attractive than normally agreed upon between an individual ASEAN country and a non-ASEAN partner. This is more political than the economic standard ordinarily adhered to by developing countries, and constitutes an exception to the most-favoured-nation standard

\section{(e) Internal Structural and Administrative Changes}

Coinciding more or less with the shift from national ASEAN secretariats to an international permanent secretariat in Jakarta, ${ }^{38}$ parallel transformation has taken place in the national secretariats within ASEAN member States. Structurally, ASEAN affairs initially came under the economic department within the Foreign Ministry of member countries while in some States the Political Department might have a small role to play. Today, each national ASEAN department is independent from the traditional department of economic affairs, with a separate Director General. Furthermore, the deputy head of mission accredited to an ASEAN country has been upgraded to the rank of Minister. Initially the annual Ministerial Meetings were attended by Ministers of Foreign Affairs assisted by their national ASEAN Secretary-General, subsequently senior officials in political affairs also accompanied the Foreign Ministers with the result that the annual Joint Communiqués now consist of two combined components, one on economic co-operation and development and the other on matters of common political concern relating to international situations or foreign affairs of the region, ${ }^{39}$ such as Cambodia, the Arab-Israel conflict, Lebanon and East Timor. Special Meetings of ASEAN Foreign Ministers have also been held to consider Political matters and to formulate an ASEAN position on the issue.

\section{(f) Restatement of Common ASEAN Posture}

Reiterating ASEAN commitment to the principle of the Bangkok Declaration of 1967 that "the countries of South-East Asia share a primary responsibility for strengthening the economic and social stability of the

\section{See infra, section 3.2.1.}

39. See, e.g., the Joint Press Release, First ASEAN Ministerial Meeting and the Second, Third, Fourth, Fifth, Sixth and Seventh Joint Communiqués, and compare the Eighth and subsequent communiqués in: ASEAN Documents (Ministry of Foreign Affairs, Bangkok, Thailand). 
region and ensuring their peaceful and progressive national development, and that they are determined to ensure their stability and security from external interference in any form or manifestation in order to preserve their national identity in accordance with the ideals and aspirations of their peoples", the ASEAN Ministers of Foreign Affairs at their Special Meeting in Kuala Lumpur on 27 November 1971 adopted the Zone of Peace, Freedom, and neutrality (ZOPFAN) Declaration, known as Kuala Lumpur ZOPFAN Declaration, agreeing that "the neutralisation of SouthEast Asia is a desirable objective and that ASEAN Ministers should explore ways and means of bringing about its realisation". ${ }^{40}$ This Declaration was warmly welcomed by China and subsequently by Japan, while developed countries in the West have shown no enthusiasm in their response, in spite of the Nixon Doctrine of Vietnamisation of the Vietnam War. ${ }^{41}$ In a subsequent Declaration of ASEAN Concord adopted by the Heads of Government of ASEAN at their Bali Summit on 24 February 1976, the ASEAN Heads of Government agreed to meet as and when necessary, signed the Treaty of Amity and Co-operation in South-East Asia, agreed to settle intra-regional disputes by peaceful means, to take steps towards recognition of and respect for ZOPFAN, to improve ASEAN machinery to strengthen political co-operation, including judicial co-operation, e.g. by way of extradition treaties, and to strengthen political solidarity by promoting harmonisation of views, co-ordinating positions and, wherever possible and desirable, taking common actions. They also agreed to continue ASEAN co-operation between member States in security matters in accordance with their mutual needs and interests on a non-ASEAN basis. ${ }^{42}$

\subsection{Co-operation with non-ASEAN Entities}

ASEAN was never conceived nor was ASEAN ever designed to function in isolation as an inward-looking association or exclusive club of South-

40. See Zone of Peace, Freedom and Neutrality Declaration, ASEAN Multilateral Treaties, Declaration No. 2, pp.18-21.

41. The Nixon doctrine was designed to pave the way for the Republican Administration to disengage US forces from Vietnam, then a hereditas jacens from the predecessor Democratic Administration. Both ZOPFAN and the Nixon doctrine could see eye to eye in that there should be no interference in South-East Asia from any outside Power, whether China, the Soviet Union or the United States. From the US standpoint, "non-involvement in Vietnamese affairs" or "let the Vietnamese fight their own wars" would be consistent with the concept of the Zone of Peace, Freedom and Neutrality, proclaimed by ASEAN in Kuala Lumpur. While non-involvement is not inconsistent with neutrality, neutralisation carries a different connotation.

42. See Declaration of ASEAN Concord, ASEAN Multilateral Treaties (Declaration No. 4), pp.24-29. 
East Asian nations. On the contrary, ASEAN is an open community to which outsiders are welcome without exception. Neighbouring South-East Asian States have attended ASEAN meetings as observers and gradually may consider it opportune to participate as full members as did indeed the rich island sultanate, Brunei Darussalam, which became the sixth member of ASEAN on 7 January $1984 .{ }^{43}$ The accession process has been as smooth as it was informal.

Informality is indeed a noteworthy characteristic of ASEAN from its very inception and in living reality, from the conception of ASEAN itself. A question which needs to be addressed is that relating to the legitimacy and constitutionality of the international personality of ASEAN without which in the eyes of international law governing international organisations ASEAN may not have come into being.

\subsubsection{International Legal Personality of ASEAN}

Specialists of the international law on international organisations may disagree with regard to the vital necessity for an international organisation to be born and blessed with an international legal personality. There is nevertheless a common ground that legal capacity to conclude treaties or international agreements is a strong evidence if not an attribute of international legal personality. An international organisation by definition must be inter-governmental, and that is all that it needs to be. There is no additional requirement that it has to have a sizable membership or population, so long as there is a constituent instrument with clear and unequivocal intention on the part of the States agreeing to its establishment. Such clear intention is discernible from the Charter of the United Nations which is the constituent instrument of the United Nations Organisation as well as a Treaty among its signatories. So also was the Bangkok (ASEAN) Declaration of 1967, regardless of its form or the lack of formality, with regard to ASEAN, notwithstanding non-registration with the United Nations Secretariat. As an accomplished "international organisation" within the meaning of the Vienna Convention on the Law of Treaties, 1969, and the Vienna Convention on Representation of States in their Relations with International Organisations..., 1975, each and every question concerning the status of ASEAN deserves a separate and in-depth study.

As part of ASEAN's legal status, the privileges and immunities in respect of ASEAN have occupied the attention of Member governments of the Association since its inception. The bottom line in practice has always

43. See Declaration on Admission of Brunei Darussalam in the Association of South-East Asian Nations, ASEAN Multilateral Treaties (Declaration No. 13), pp.64-67. 
been that the host country agrees to accord whatever privileges and immunities are customarily accorded to international organisations such as the United Nations. In other words, the extent of the immunities and privileges granted is circumscribed by the functional necessities of the organisation or the performance of its official functions. Not unlike other more established international organisations, ASEAN was not born with a readymade Convention on Privileges and Immunities. Such a treaty has to be proposed, negotiated, accepted, concluded, ratified and come into force, like any other formal international agreement. ASEAN was not even born with a unified single secretariat but with five national Secretary-Generals, comparable in some respects to the Canadian-US Free Trade Association with its Bilateral Secretariat. Almost ten years after its birth, ASEAN was blessed with a central ASEAN Secretariat. ${ }^{44}$

The privileges and immunities are not contained in a general convention but in an agreement which is more like a combination of the United Nations Convention on Privileges and Immunities of 1946 and the Headquarters Agreement between the United States and the United Nations. It is concluded as an Agreement between the Government of Indonesia and ASEAN [the Organisation] relating to the Privileges and Immunities of the ASEAN Secretariat, Jakarta, 20 January $1979 .{ }^{45}$ Clearly, ASEAN privileges and immunities extend also to other offsprings, organs and centres association with the Organisation, such as the ASEAN Centre for Trade, Investment and Tourism in Tokyo, or the ASEAN Trade Centre in Rotterdam. Further study deserves to be undertaken on these aspects.

\subsubsection{Co-operation with other International Organisations}

ASEAN member States clearly recognize ASEAN as a regional organisation from the very start. Within the legal system of each of the ASEAN founding members, the Association has received tacit, if not express, recognition by the establishment of official relations with each member country and the preparation of studies, documents, etc., for various ASEAN meetings at different levels in compliance with obligations under the ASEAN constituent instrument. What was urgently needed was the facility to conduct relations with the outside, i.e., non-ASEAN, world, and particularly with the many pre-existing regional bodies, commissions and organisations. Contact with these organisations would imply recognition by

44. See Agreement on the Establishment of the ASEAN Secretariat, 24 Feb. 1976 (Bali Summit), and Joint Communique of the ASEAN Ministerial Meeting, Manila, 24-26 June 1976, para. 20. The Agreement has so far been amended by two Protocols, in 1903 and 1905.

45. ASEAN Document Series 1967-1988 (third edition, published by ASEAN Secretariat, Jakarta, 1988), pp.165-176. 
them. The first such contact came in 1968 from the then United Nations Economic Commission for Asia and the Far East (ECAFE, now ESCAP) relating to an offer of assistance from an EEC member, Belgium, for an ASEAN study. ${ }^{46}$ Negotiation and conclusion of an agreement with the United Nations were the first acts of mutual recognition and the first relations with the outside world. ASEAN was represented by the Chairman of its Standing Committee in Jakarta, then Minister ADAM MALIK. It was in fact a break-through to countless contacts and fruitful relations with the outside world. Within the United Nations, ASEAN has established ASEAN Committees of Accredited Representatives in New York as well as in Geneva.

It should be recalled that ASEAN was conceived through the indigenous efforts of its founding members, unassisted and unattended by outsiders. By that time, the UN Economic Commission for Asia and the FarEast (ECAFE) had been actively urging its regional members to create regional groupings for economic co-operation. Thus the Mekong Committee, consisting of Laos, Cambodia, Thailand and Vietnam came into existence under its auspices and still functions as such until these days and the Asian Development Bank (ADB) in Manila could be considered as an offspring of ECAFE although quite independent of the regional Commission. ECAFE was anxious to woe ASEAN, and the first opportunity came at the Second Ministerial Meeting in Jakarta, 16-18 August 1968 in connection with the Belgian-sponsored ASEAN study (see supra). When the preliminary report was submitted and reviewed by the ASEAN Ministers at its fourth meeting in Manila, 12-13 March 1971, the Ministers directed that sectoral studies be pursued (para. 9 of the Joint Communiqué). Again, at the Fifth Ministerial meeting in Singapore in 1972, the ASEAN Ministers expressed appreciation of the United Nations Study Team and urged Member Governments to study the Team's recommendations with a view to identifying areas in which ASEAN could co-operate more meaningfully, seeking continued United Nations technical assistance vital for the implementation of the recommendations by the United Nations Team. This task of identifying the areas of fruitful ASEAN co-operation was then assigned to a newly formed Special Co-ordinating Committee for ASEAN (SCCAN), chaired by Dr. SOEMITRO, the Co-ordinating Economic Minister of Indonesia. Relations with the United Nations through its regional Commission have been thorough and extensive, covering activities of the Specialised Agencies of the United Nations, such as FAO, WHO and WMO, as well as other subsidiary organs of the United Nations such as UNDP and UNHCR. Even non-governmental organisations such as ICRC (International Com-

46. See Joint Communiqué, Second ASEAN Ministerial Meeting, Jakarta, August 6-7, 1968, para 6 , welcoming the offer of services made by ECAFE to carry out an economic survey, ASEAN Documents (Ministry of Foreign Affairs, Bangkok), pp.120-121, also in op.cit. n.42 at p.69. 
mittee of the Red Cross) have maintained contacts and active relations with ASEAN. ASEAN has from its birth been showered with invitations to maintain relations with existing international organisations, and has itself created or generated subsidiary organs, offices and centres within and outside ASEAN member countries. It has concluded countless international agreements, not all of which have been registered with the United Nations, and its co-operation with other international organisations and nongovernmental organisations (NGOs) has generated sufficient materials for a separate volume beside the present study.

\subsubsection{Co-operation with EEC}

Since the establishment of the ASEAN Brussels (EEC) Committee [ABC] in 1972, relations between ASEAN (and its member States) and EEC (and its member States) have grown by leaps and bounds, culminating in the Co-operation Agreement between the member countries of ASEAN and the EEC on 7 March $1980,{ }^{47}$ following successive ASEAN-EEC Ministerial Meetings in Brussels (1975) ${ }^{48}$ and Kuala Lumpur $(1980)^{49}$. The ASEAN-EEC Cooperation Agreement set out the basic principles of most-favoured-nation treatment, co-operation in trade and development and economic co-operation, and a joint co-operation committee was set up. EEC now maintains an office in Bangkok, an ASEAN capital, for its relations with countries in Asia, except Japan. ${ }^{50}$ ASEAN-EEC co-operation forms a subject of intense cultivation from the very early years of ASEAN's existence. The EEC has been willing and prepared to conduct negotiations with ASEAN, both as between regional bodies or communities and with the member States individually. Collective as well as several arrangements have been concluded between EEC and ASEAN and between their respective member States.

\subsubsection{Co-operation with Countries in South-East Asia}

ASEAN continues to play an active role in its co-operation with neighbouring States in South-East Asia including Laos, Cambodia and Myanmar (Burma). Relations with Vietnam have undergone some fluctuations but appear to have improved since the withdrawal of Vietnamese forces from

47. See ASEAN-EEC Co-operation Agreement, 7 March 1980, ASEAN Multilateral Treaties (Agreement No. 14), pp.176-182.

48. See ASEAN Documents, op.cit. n.37, pp.235-240.

49. lbid., pp.240-245; see also the Meetings in London, 1981, ibid., pp.145-247, and in Bangkok, 1983, ibid., pp.247-252.

50. It should be noted that the EEC maintains only three permanent missions of ambassadorial rank, viz., Washington, Tokyo and Bangkok. 
Cambodia. It should be recalled that one of the ASEAN founding members, Thailand is inextricably linked with Myanmar and the former French IndoChinese States, Laos, Vietnam and Cambodia, the last three through the United Nations Committee of the Co-ordination and Investigation of the Lower Mekong Basin. With the South-East Asian States adjacent to Thailand ASEAN as a whole maintains close relations through Thailand. It should be remembered that Papua New Guinea has been invited to attend ASEAN Ministerial Meetings since the early 1980s, even before the admission of Brunei Darussalam.

\subsubsection{Co-operation with Dialogue Partners}

The expression "dialogue countries" or "dialogue partners" has been used in the context of ASEAN co-operation with third countries to which special attention has been given, because of their regional significance in economic or political terms. More precisely, the dialogue countries collectively are referred to occasionally as the "ASEAN PLUS". They are the "Plus" or extension of ASEAN co-operation, not exactly third countries, but more close "Trading Partners".

It is most intriguing to examine the relationship between ASEAN and each of its dialogue partners, with which ASEAN maintains the closest connections. Each year after the Annual Ministerial Meeting, the ASEAN Ministers meet with the Ministers of its dialogue partners, one by one, or as a collectivity such as the EEC. It is beyond the scope of this preliminary study to cover exhaustively all of the dialogues that have taken place between ASEAN and each of the ASEAN PLUS partners. Suffice it, in an introduction to ASEAN, to give but a brief sample survey of the productive cooperation with some of them.

(a) ASEAN-Japan

In spite of Japan's invasion and occupation of large portions of ASEAN territory during World War II and the ensuing blood-bath in the Philippines, Indonesia, Singapore and Malaysia, ASEAN countries stand ready to co-operate with Japan on the understanding that the latter adheres to a code of conduct prescribed by ASEAN, especially "Equality of Partnership" and not "Domination or Hegemony" or anything reminiscent of the unforgettable "Co-Prosperity Sphere" 51 under which Japan indiscriminately invaded her Asian neighbours. ASEAN-Japan dialogue started in 1977

51. Japan needs an occasional reminder. Thus, Prime Minister KAlFu proposed the Kaifu Doctrine declaring the intention to propose a Free Trade Area between Japan and East-Asia, including ASEAN, knowing full well that Japan remains closed to ASEAN agricultural products but wishes to exploit still further the open ASEAN market. 
with a summit meeting. A half-hearted measure is Japan's hosting the ASEAN Promotion Centre on Trade, Investment and Tourism in Tokyo since $1980 .^{52}$ Several obstacles remain to be overcome for the opening of Japan's market to products from ASEAN. Unlike the unique Centre for the Promotion of Import from South-East Asia in Rotterdam, the Netherlands, which has been beneficial to ASEAN, Japan maintains an active and aggressive export policy through its export Trade Organisation (JETRO). Trade problems with Japan continue to exist. Japan needs to be constantly reminded not only of her past misdeed from which each ASEAN State has suffered, but, more significantly, of her dependence on ASEAN for the supply of basic raw materials, and of ASEAN's strategic position. Japan cannot afford any posture that appears hostile to ASEAN, and must suppress antiASEAN sentiments at any cost and at all time. To provoke ASEAN's unfriendly reactions may spell the collapse of Japan's economy. Japan would cease to be an economic power within a short time if no crude could flow through the Malacca, Lombok, or Sunda straits. Perhaps a pipeline could be laid across the Kra Isthmus in Southern Thailand, but again, Thailand is part and parcel of ASEAN which Japan should refrain from antagonising.

On the other hand, it should equally be recalled that since the predawn of the new Pacific Era, Japan has found great comfort in ASEAN surroundings. In spite of past bitter experience, Japan has found a way, in her own unskilled manner, to made amends. Since ASEAN has always been Japan's closest and natural market, a healthy and rather up-coming market of 300 million population, Japan has invested more heavily in ASEAN countries than any of the other ASEAN dialogue partners. Whatever Japan's shortcomings in her own cultural developments, Japan has contributed no less than five billion yen to the ASEAN Cultural Fund in 1979 and 1980, in addition to the scholarship grants for ASEAN youth and the "Friendship Youth Boat' launched by Prime Minister Tanaka in 1974, following his tour of ASEAN countries. ${ }^{53}$

\section{(b) ASEAN - Canada}

ASEAN-Canadian dialogue may have started somewhat late after ASEAN dialogue with Japan, Australia and New Zealand, but since the Summit of 1977 Canada has been much faster on the uptake. Thus an agreement between the member countries of ASEAN and Canada on economic

52. See the Agreement Establishing the ASEAN Promotion Centre on Trade, Investment and Tourism in Tokyo, ASEAN Multilateral Treaties (Agreement No. 14), pp.184-194.

53. The "Friedship Youth Boat was a floating experiement to put, origianlly, ten young boys and girls from each of the ASEAN countries and from Japan afloat the Pacific Ocean and off Japanese and ASEAN shores and to monitor the reactions among the young persons. Greater mutual understanding has been made possible the tensions between ASEAN and Japanese youth somewhat reduced if not relaxed and dormant but ambulatory. 
co-operation was signed on 25 September $1981,{ }^{54}$ setting out broad principles and guidelines for co-operation in all fields including industrial (Articles I-IV), commercial (Articles V-IX) and development (Articles IX-XIV), and the establishment of institutional arrangements. A Joint Co-operation Committee was set up to review the various co-operation activities envisaged in this agreement which has in fact proved mutually beneficial for all parties.

\section{(c) ASEAN-Australia}

ASEAN-Australian dialogue started in 1974, even before the ASEAN-Japan Summit. Co-operation with Australia has been fruitful and several ASEAN projects were implemented. Six fora existed by 1981 for ASEANAustralia Economic Co-operation Projects (AAECP), many of which have now come to fruition. The list of pending projects gives an accurate notion of how intense and wide-ranging ASEAN-Australian co-operation has evolved, including contracts to explore and exploit mineral resources in East Timor. ${ }^{55}$

\section{(d) ASEAN-New Zealand}

ASEAN-New Zealand co-operation began in 1975, followed by the Summit Dialogue in 1977. Not dissimilar from Australia, New Zealand has maintained the position of a friendly and beneficial partner of ASEAN in trade as well as in development promotion.

\section{(e) ASEAN-USA}

The co-operation between the United States and ASEAN started on political issues. The United States supported the ASEAN position and draft resolutions on Cambodia since 1979. Since 1981 a dialogue between the United States and ASEAN has taken place on a regular basis. In 1982, six ASEAN projects were approved in agriculture, public health, and academic training. Now the United States ranks as one of ASEAN's closest trading partners, with whom ASEAN countries maintain annual ministerial dialogues in the same manner as Japan, Canada, Australia and New Zealand. ${ }^{56}$

\section{(f) ASEAN-USSR ${ }^{57}$}

The next candidate on the list of future ASEAN partners in trade and economic co-operation could be the Soviet Union. Since the operation of

54. See ASEAN Multilateral Treaties (Agreement No. 17), pp.201-210.

55. See, generally, Annual Report of the ASEAN Standing Committee for the years 1989 and 1990.

56. For an interesting analysis of US-ASEAN Relations in Thai-American Relations in Contemporary Affairs (Executive Publications PTE Ltd., Singapore, 1982).

57. Editorial note: The present paper was completed before the recent developments of November-December 1991. 
Glasnost and Perestroika and with the withdrawal of Soviet support of the Vietnamese occupation of Cambodia, the timing is right. The obstacle to meaningful relations with the USSR has been removed. There might be a more balanced peace and harmony in the region with more active participation by the USSR.

(g) Co-operation with other Asian Nations

China, Hong Kong, Taiwan, Korea and India may be next in line for closer bilateral relations with ASEAN. A more complete and balanced series of co-operation will than take shape for ASEAN.

\section{CONCLUDING OBSERVATIONS}

The foregoing survey of ASEAN activities in various fields of co-operation among the member States themselves as well as with the outside world may not lend itself to a readily discernible conclusion. Whatever criticism outsiders may have levelled against ASEAN, whether it relates to slowness, lack of aggressiveness, insufficiency in the degree of integration, or even absence of outward signs of more democratic institutions from a Westerner's perspective, ASEAN must be gratified by its glaring achievements. In the first place, since ASEAN was launched into orbit, the Association has managed to retain the fullest measure of sovereignty, political independence and territorial integrity of each of its member States. Its membership has increased which reflects on the nature of ASEAN's continuing growth. ASEAN credibility remains intact. Secondly, ASEAN has succeeded in putting aside whatever internal differences or conflicts it has encountered between its members, thereby reducing tensions in the region and strengthening regional stability and solidarity. Thirdly, notwithstanding its imperfections, ASEAN has received universal recognition and is known throughout in every international and regional forum, where friendly relations and fruitful co-operation have been assured. ASEAN's strength is appreciated in a political organisation such as the United Nations, and in the Specialised Agencies such as GATT, or other bodies such as UNCTAD and the Group of 77, as well as in its relations with the EEC with which it has established a firm and sound relationship. Fourthly, ASEAN resilience has been recognised and continues to play a stabilising role in the political development in the region of South-East Asia in regard to Cambodia and Vietnam as well as in other areas of conflict such as the Arab-Israel conflict and the conflict in Lebanon. Lastly, but not least, whatever its shortcomings, the Association has steered its way through several storms of world-wide economic recession, and each time ASEAN has come out stronger with renewed vigour. Admittedly, the expansion of trade, in- 
vestment and tourism in each and every country of ASEAN has been and continues to be phenomenal even in the height of global recession or stagflation. Due to its inherent outward-looking character, ASEAN not only promotes co-operation within the region of South-East Asia but has demonstrated its capacity and desire to co-operate meaningfully with the rest of the world.

As ASEAN is steadily progressing as an association for regional economic co-operation and as a viable regional organisation expanding its trade, investment and tourism, it has looked beyond national and regional confines. It has found the various agencies of the UN such as its regional commission and UNDP, as well as the EEC to be its natural partners for fruitful collective negotiations and co-operation. Other natural trading partners of ASEAN are inevitably Japan, Australia, New Zealand, Canada and the United States. This by no means detracts from the growing trade expansion ASEAN countries enjoy with other trading partners, namely, the other three Asian tigers, Korea (ROK), Taiwan and Hong Kong, all of which have heavily invested in development projects in ASEAN countries. The relations with China and the USSR continue unabated both on the economic and political fronts. The future of the former Indo-Chinese States, regardless of their economic or political structure, is tied up with one of the ASEAN members, Thailand, in the Lower Mekong Basin, which also touches Myanmar and Southern China. The largest Socialist countries, both China and the USSR have paid special attention to bilateral co-operation with ASEAN during the frequent visits of their leaders to each ASEAN nation.

The lesson to be drawn from this preliminary introduction to the Association of South-East Asian Nations is that the unity of purpose, solidarity, consciousness, resilience and dynamism of ASEAN partnership have brought ASEAN nations together on a collective road to peace and stability, to progress and prosperity. The fact that each of the six ASEAN nations has achieved wonders in its outstanding economic growth and industrial development should provide living testimony to the success of the principles and objectives of ASEAN, enshrined in the oft-cited Bangkok Declaration of 8 August 1967, based on the practice of equality of partnership, mutuality of benefits and complementarity in energy and industrial production. 